\title{
PERLNDUNGAN HUKUM TERHADAP IBU PENGGANTI (SURROGATE MOTHER) YANG MENGIKATKAN DIRI DALAM PERJANJIAN SEWA RAHIM (SUROGASI) DI INDONESIA
}

\author{
Lintang Wistu Malindi \\ lintang204@gmail.com \\ Mahasiswa Magister Ilmu Hukum Universitas Sebelas Maret Surakarta
}

\begin{abstract}
This study aims to analyze the legal protection on Surrogate Mother who bound into Surrogate M other Agreement alongside the existence of Surrogate M other Agreement based on Indonesia's Civil Law. This tudy is normative legal research with analysis descriptive characteristic. The approach which was used in this research was statute approach. Type of data which was used in this research was secondary data which included primary legal materials and secondary legal materials. The technique of collecting the data in this research was literature study. Analytical technique in this research was done by law interoretation.The result shows that there are many violation on ther rights against Surrogate Mother cause there is no strong legal protection. Therefpre, there is a eed for strong legal protection from the state through its legislations policy.
\end{abstract}

Keywords: Surrogate Mother, Surrogacy Agreement, Legal Protection.

\begin{abstract}
Abstrak
Kajian ini bertujuan untuk menganalisa perlindungan hukum terhadap ibu pengganti yang mengikatkan diri dalam perjanjian sewa rahim sekaligus eksistensi oerjanjian sewa rahim dalam perspektif hukum perdata di Indonesia. Penelitian ini merupakan penelitian hukum normatif yang ebrsifat deskriptif analitis. Pendekatan yang digunakan dalam penelitian ini ialah pendekatan undang-undang. Jenis data yang digunakan dalam penelitian ini ialah data sekunder yang terdiri atas bahan hukum primer dan bahan hukum sekunder. Teknik pengumpulan data yang digunakan ialah melalui studi kepustakaan. Analisis data dilakukan melalui penafsiran hukum. Hasil penelitian menunjukkan bahwa terdapat pelanggaran hakhak asasi ibu pengganti karena tidak adanya perlindungan hukum yang kuat. Maka dari itu diperlukan perlindungan hukum yang kuat dari negara melalui legistasinya.
\end{abstract}

Kata Kunci: Ibu Pengganti, Perjanjian Sewa Rahim, Perlindungan Hukum.

PENDAHULUAN

\section{Latar Belakang}

Keberlangsungan untuk melanjutkan keturunan telah diatur dalam Pasal 28 B ayat (1) Undang-Undang Dasar Republik Indonesia Tahun 1945 dan Pasal 10 ayat (10) UndangUndang Nomor 39 Tahun 1999 tentang Hak-Hak Asasi Manusia yang menyatakan 
bahwa setiap orang. Meskiun melanjutkan keturunan mrupakan salah satu hak asasi manusia yang dijamin dan dilinduingi oleh hukum,, pada kenyataannya tidak semua pasangan suami istri memiliki kesempatan memperoleh keturunan dengan mudah. Bahkan banyak dari mereka yang tidak dikaruniai anak karena masalah infertilitas. Hasil penelitian memperlihatkan kurang lebih $10 \%$ (sepuluh per seratus) pasangan suami istri tidak memiliki kesempatan memiliki anak karena masalah infertilitas dan kecil kemungkinan bagi mereka melakukan adopsi anak. ${ }^{1}$ Hal ini tentu saja menyebabkan pasangan suami istri mengalami keputusasaan dan pada akhirnya memaksa mereka mencoba alternatif lain untuk mendapatkan seorang anak atau keturunan.

Dewasa ini, dengan perkembangan teknologi yang begitu pesat menciptakan suatu teknologi baru dalam dunia kesehatan yang dapat membantu proses reproduksi. Teknologi baru dalam proses reproduksi yang dapat membantu pasangan suami istri dalam memperoleh keturunan dikenal dengan istilah sistem Assisted Reproductive Technology (ART). Salah satu metode yang banyak diaplikasikan adalah metode In Vitro Fertilization atau dalam bahasa sehari-hari sering disebut dengan istilah bayi tabung. ${ }^{2}$ Metode ini ditemukan sekitar tahun 1970-an guna bertujuan memberi solusi kepada suami istri yang sulit memiliki keturunan. ${ }^{3}$ Bayi tabung ialah individu (bayi) dimana penciptaanya terjadi di luar tubuh atau ditempuh dengan cara inseminasi buatan ${ }^{4}$

Setelah kemunculan bayi tabung nyatanya membuat teknologi dalam proses reproduksi semakin berkembang. Hal ini dapat dilihat dari adanya alternatif lain yang ditawarkan untuk memperoleh keturunan. Alternatif lain yang dimaksud adalah dengan metode surogasi atau disebut juga dengan sewa rahim. Surogasi ialah metode atau persetujuan dari seorang wanita agar mengandung untuk orang lain yang nantinya akan menjadi orang tua dari anak yang dikandung dan dilahirkan wanita tersebut . ${ }^{5}$ Sewa rahim

\footnotetext{
${ }^{1}$ Zahrowati, “ Bayi Tabung (Fertilisasi In vitro) dengan Menggunakan Donor Sperma dan Rahim (Surrogate Mother) dalam Perspektif Hukum Perdata", Halu Oleo Law Review (HOLREV), vOL 1, Issue 2, (September, 2017). hlm.127.

${ }^{2}$ Bella Habibilah dan Wismar Ain, “Kedudukan Hukum Anak Yang Dilahirkan Melalui Ibu Pengganti (Surrogate Mother) Ditinjau Dari Hukum Kekeluargaan Islam”, Lex Jurnalica, Vol 12, No 2, (Agustus,2015),hlm.153.

${ }^{3}$ Aditya Wiguna Sanjaya, "Aspek Hukum Sewa Rahim (Surrogate Mother) dalam Perspektif Hukum Perdata dan Hukum Pidana”, Jurnal Rechtens, Vol 5, No 2, ( Desember, 2016), hlm.37.

4 Syarif Zubaidah, "Bayi Tabung, Status Hukum, Hubungan Nasabnya Dalam Perspektif Hukum Islam", Al Mawarid Edisi VII, (Februari, 1999), hlm. 46.

${ }^{5}$ J Srinivas and Matin Ahmad Khan,"Surrogacy in India: Current Perspective”, International of Health and Medical Research, Vol 3, Issue 5, ( May. 2017), hlm. 85.
} 
dilakukan dengan suatu perjanjian atau kontrak yang biasa disebut sebagai perjanjian sewa rahim atau kontrak sewa rahim. Kontrak ini ialah suatu perjanjian antara seorang wanita yang mengikatkan diri dengan pasangan suami istri untuk mengandung dan menyerahkan bayi tersebut kepada pihak lain.$^{6}$ Kontrak ini pada dasarnya menetapkan seorang wanita yang mengandung calon bayi orang lain untuk menyerahkan haknya sebagai ibu kepada pihak ketiga ${ }^{7}$ Praktik surogasi sebenarnya tidak jauh berbeda dengan bayi tabung, namun bedanya di sini dalam surogasi yang mengandung ialah Surrogate Mother yang bersedia untuk mengandung dan melahirkan anak untuk wanita lain karena alasan finansial ataupun kepedulian. ${ }^{8}$ Praktik telah berkembang di berbagai negara di dunia bahkan di Amerika Serikat praktik ini merupakan fenomena yang ada sebelum perang saudara dimana budak wanita dijadikan ibu penngganti oleh pemiliknya ${ }^{9}$. Sementara itu India muncul sebagai negara paling banyak mempraktikkan surogasi sebagai contoh di daerah Cjenna yang memfasilitasi surogasi dengan lebih dari 12 rumah sakit untuk prosedur surogasi. ${ }^{10}$

Meskipun praktik surogasi menjadi alternatif lain dalam memperoleh keturunan, nyatanya kemunculan surogasi di beberapa negara masih menjadi perbincangan dan perdebatan dimana surogasi bergeser ke arah ekonomi dan eksploitasi yang dilihat dari kemunculan surogasi sebagai lading bisnis, sebut saja India yang memperoleh pemasukan sekitar 4 Trilyun per tahun dari surogasi. ${ }^{11}$ Kemudian terdapat problematika etik ketika rahim dianggap sebagai wadah atau "inkubator" manusia untuk orang lain ${ }^{12}$. Kemudian praktik ini juga dianggap berbahaya bago ibu penggati dan membahayakan masyarakat. ${ }^{13}$

\footnotetext{
${ }^{6}$ Fajar Bayu Setiawan, dkk, “ Kedudukan Sewa Rahim dalam Hukum Positif Indonesia”, Private Law Edisi 01 Maret-Juni, 2013, hlm. 67.

${ }^{7}$ Lorenzo Del Savio and Glulia Cavaliere, “ The Problem With Commercial Surrogacy, A Reflection Reproduction, Markets and Labour", BioLaw Journal-Rivista di BioDiritto, Np 2, 2016,hlm. 74.

${ }^{8}$ Anton Van Niekerk and Liez; Van Zyl, “The Ethic of Surrogacy: Women:s Reproductive Labour”, Journal of Medical Ethic Vol 21, 1995, hlm 245.

${ }^{9}$ Carla Spivack, "National Report: the Law of Surrogate Motherhood in Uniterd State", The American Journal of Comperative Vol 58, 2010, hlm 97

${ }^{10}$ Alifah Rahmawati dan Hirma Susilowati, "Fenomena Surrogate Mother dalam Perspektif Islam Ditinjau dari Hadits", Nuansa Vol 14 No 2, Juli-Desember 2017, hlm 412

${ }^{11}$ Sonny Dewi Judiasih dan Susilowati S Dajaan, "Aspek Hukum Surrogate Mother dalam Perspektif Hukum Indonesia", Jurnal Bina Mulia Hukum Vol 7 No 2, Maret 2017,142/

12 Hugh V McLachan, "Defending Commercial Surrogate Motherhood Againts Van Niekerk and Van Zyl", Journal of Medical Ethics Vol 23, 1997, hlm 345.

${ }^{13}$ Lina Peng, "Surrogate Mother: An Exploration of The Empirical and The Normative", American University Journal of Gender, Social Policy, and The Law Vol 21 Issue 3 Art 2, 2013, hlm 556.
} 
Perdebatan juga tidak terkecuali di Indonesia. Hal ini dikarenakan keberadaan praktik ini belum diatur di Indonesia. Seperti yang diketahui berdasarkan UndangUndang Nomor 36 Tahun 2009 tentang Kesehatan Pasal 127 ayat (1) dinyatakan didalamnya bahwa metode pembuahan di luar cara alamiah yang diakui ialah metode bayi tabung. Selain itu kehadiran praktik ini menimbulkan berbagai permasalahan misalnya saja terkait dengan kepastian hukum baik dari perjanjiannya maupun pelaksanaan praktiknya yang pada akhirnya berdampak pada kedudukan anak yang dilahirkan oleh seorang ibu pengganti. Namun bukan hanya itu saja, permasalahan juga muncul dari adanya berbagai pelanggaran terhadap hak-hak asasi dari ibu pengganti dimana pada kenyatannya cenderung terjadi eksploitasi dan tidak terlindunginya hak-hak ibu pengganti sebagai manusia yang memiliki hak asasi ataupun sebagai seorang perempuan.

Permasalahan dari adanya praktik surogasi nampaknya telah menjadi perhatian yang menyebabkan munculnya penelitian-penelitian terdahulu terkait dengan praktik surogasi. Sebagai contohnya ialah penelitian hukum atas nama Muhammad Ali Hanafiah Selian dari Fakultas Syariah dan Hukum Universitas Islam Negeri (UIN) Syarif Hidayatullah Jakarta dengan judul "Surrogate Mother: Tinjauan Hukum Perdata dan Islam” pada tahun 2017 yang mengkaji tentang pengaturan surogasi berdasarkan hukum perdata dan Islam. Contoh lain ialah penelitian hukum atas nama Zahrowati pada tahun 2017 dengan judul “ Bayi Tabung (Fertilisasi In Vitro) dengan Menggunakan Sperma Donor dan Rahim Sewaan (Surrogae Mother) dalam Perspektif Hukum Perdata" yang mengkaji secara komprehensif kedua metode reproduksi secara inseminasi buatan yakni bayi tabung dan surogasi dipandang dari perspektif hukum perdata di Indonesia. Contoh penelitian lain ditunjukkan oleh penelitian dengan judul "Aspek Hukum Surrogate Mother Dalam Perspektif Hukum Indonesia” oleh Sonny Dewi Judiasih dan Susilowati S Dajaan dari Fakultas Hukum Universitas Padjajaran pada tahun 2016 yang mengkaji keberadaan perjanjian surogasi berdasar hukum positif di Indonesia dengan membandingkannya dengan pengaturan surogasi di beberapa negara. Contoh tersebut merupakan beberapa penelitian terdahulu terkait dengan keberadaan surogasi.

Berdasarkan uraian tersebut di atas, maka muncul ketertarikan penulis untuk mengkaji fenomena baru yakni praktik surogasi dalam masyarakat Indonesia yang pada 
kenyataanya menimbulkan beberapa problematika. Ketertarikan penulis di sini lebih terfokus pada kedudukan perjanjian sewa rahim menurut perspektif hukum perdata di Indonesia dan menyangkut perlindungan hukum terhadap ibu pengganti yang mengikatkan dirinya dalam perjanjian surogasi berdasarkan berbagai peraturan yang ada di Indonesia .

\section{Rumusan Masalah}

Berdasarkan uraian latar belakang di atas maka rumusan masalah dari permasalahan penulis ialah:

a. Bagaimana kedudukan perjanjian sewa rahim (surogasi) berdasarkan hukum perdata di Indonesia?

b. Bagaimana perlindungan hukum terhadap ibu pengganti yang mengikat dirinya dalam perjanjian sewa rahim di Indonesia?

\section{Metode Penelitian}

Guna memecahkan masalah hukum maka dilakukan suatu penelitian hukum. Penelitian hukum ini ialah kegiatan know-how untuk memecahkan isu hukum. ${ }^{14}$ Penulisan hukum ini merupakan penelitian hukum normatif yang didasarkan kepada bahan pustaka. Penelitian hukum ini bersifat deskriptif analitis yang menggambarkan gejala guna mendapatkan data seteliti mungkin mengenai gejala tententu ${ }^{15}$. Penelitian hukum ini menggunakan pendekatan undang-undang. Adapun data yang digunakan dalam penelitian hukum ini ialah data sekunder yang diperoleh dari bahan-bahan pustaka, ${ }^{16}$ berupa bahan hukum primer dan bahan hukum sekunder. Bahan hukum tersebut didapat melalui suatu studi perpustakaan yang nantinya akan diolah secara kualitatif dengan menguraikan bahan hukum dalam bentuk kalimat yang teratur, runtun, logis, tidak tumpang tindih, dan efisien sehingga memudahkan interpretasi secara mendalam berbagai aspek sesuai lingkup penelitian dimana dihasilkan kalimat yang sistematis sehingga akan diperoleh suatu gambaran yang jelas dan pada akhirnya dapat ditarik kesimpulan sebagai jawaban dari isu hukum berkaitan dengan perlindungan hukum terhadap ibu pengganti dalam praktik sewa rahim di Indonesia.

\footnotetext{
${ }^{14}$ Peter Mahmud Marzuki,2014, Penelitian Hukum Jakarta: Prenadamedia Group, hlm 35.

${ }^{15}$ Seorjono Seokanto, Pengantar Penelitian Hukum, (Jakarta: UI Press, 2015), hlm 10

${ }^{16}$ Seorjono Seokanto dan Sri Mamuji, Penelitian Hukum Normatif Suatu Tinjauan Singkat, (Depol: Pt Raja Grafindo Persada, 2011), hlm 12.
} 


\section{PEMBAHASAN}

\section{Kedudukan Surogasu Dalam Perspektif KUHPerdata}

Perjanjian adalah suatu ikatan janji pihak satu kepada pihak lain atau peristiwa dimana dua orang saling janji untuk berbuat suatu hal. Yang dimaksud "hal" disini ialah objek perjanjian yang telah disepakati kedua pihak tersebut. Perjanjan sendiri merupakan sumber dari perikatan yang merupakan suatu hubungan hukum antara kedua belah pihak dimana pihak satu berhak menuntut sesuatu, sementara pihak yang lain berkewajiban memenuhi sesuatu yang diminta pihak yang berhak menuntut sesuatu ${ }^{17}$. Layaknya perjanjian pada umumnya, maka perjanjian surogasi haruslah memenuhi ketentuan hukum perjanjian Ketentuan mengenai perjanjian telah diatur dalam Buku III KUHPerdata tentang Perikatan. Berdasarkan Pasal 1320 KUHPerdata ditentukan bahwa untuk sahnya suatu perjanjian diperlukan empat syarat antara lain: (1) kesepakatan para pihak untuk mengikatkan diri; (2) kecakapan untuk melakukan perikatan; (3) suatu hal tertentu; (4) suatu sebab yang halal. Keempat syarat harus dipenuhi agar perjanjian dianggap sebagai perjanjian yang sah. Syarat kesepakatan dan syarat kecakapan dalam, melakukan perikatan merupakan syarat subjektif yang jika tidak terpenuhi maka perjanjian dapat dibatalkan dan perjanjian dianggap tetap ada ${ }^{18}$, sedangkan syarat suatu hal tertentu dan sebab yang halal merupakan syarat objektif yang apabila tidak terpenuhi maka perjanjian batal demi hukum dan perjanjian dianggap tidak pernah ada. Bertolak pada syarat sahnya perjanjian, maka perjanjian surogasi haruslah memenuhi keempat syarat di atas. Adapun uraian syarat-syarat tersebut ialah:

a. Sepakat mereka yang mengikatkan diri

Ketentuan mengenai kesepakatan para pihak diatur dalam Pasal 1320 ayat (1) KUHPerdata. Kesepakatan ialah persesuaian pernyataan kehendak antara kedua belak pihak. ${ }^{19}$ Kesepakatan dianggap tidak sah jika ada kekhilafan (dwaling) yang diatur dalam ketentuan Pasal 1322 KUHPerdata, paksaan (dwang) yang diatur dalam ketentuan Pasal 1323 KUHPerdata, dan penipuan (bedrog) yang diatur dalam ketentuan Pasal 1328 KUHPerdata ${ }^{20}$ Kesepakatan disini diartikan sebagai kemauan

\footnotetext{
${ }^{17}$ Subekti, Pokok-Pokok Hukum Perdata, (Jakarta: Intermasa, 2011), hlm.123.

${ }^{18}$ Abdulkadir Muhammad, Hukum Perdata Indonesia, (Bandung: PT Citra Aditya, 2014), hlm 293.

${ }^{19}$ Ratna Artha Windari, Op.cit.,hlm 15.

${ }^{20}$ Evi Ariyani,Hukum Perjanjian, (Yogyakarta: Ombak, 2013., hlm 16.
} 
yang bebas untuk mengadakan suatu perjanjian. Kemauan yang bebas dianggap tidak ada apabila jika kata sepakat terjadi adanya kekhilafan, penipuan, atau paksaan. Dalam konteks perjanjian surogasi maka diperoleh bahwa para pihak yang terlibat atau pembuat perjanjian ini ialah seorang wanita yang bersedia menjadi ibu pengganti dan pasangan suami istri ( orang tua genetis) dari bayi yang nantinya dikandung dan dilahirkan oleh ibu pengganti. Kesepakatan antara para pihak dalam perjanjian surogasi ini dapat dilihat dari adanya kesediaan kedua belah pihak untuk terlibat dalam perjanjian surogasi ini. Kesediaan yang dimaksud disini ialah kesediaan ibu pengganti untuk meminjamkan rahimnya guna ditanami bakal calon bayi hasil pembuahan pasangan suami istri di luar rahim, serta kesediaan untuk mengandung dan melahirkan bayi tersebut. Kesediaan juga ditunjukkan oleh pasangan suami istri sebagai wujud kesepakatan yakni kesediaan pasangan suami istri tersebut untuk memberikan imbalan jasa berupa uang atau materi kepada si ibu pengganti serta menanggung berbagai biaya medis yang harus dikeluarkan selama proses sewa rahim. Kesediaan kedua belah pihak tersebut dituangkan dalam sebuah perjanjian tertulis yang telah disepakati dan harus dipatuhi oleh kedua pihak yang membuatnya.

b. Kecakapan untuk membuat suatu perikatan

Kecakapan dalam hal pembuatan perjanjian bermakna sebagai kemampuan untuk melakukan perbuatan hukum. Perbuatan hukum ialah perbuatan yang menimbulkan suatu akibat hukum. ${ }^{21}$ Ketentuan mengenai kecakapan ini menyebabkan para pihak yang melakukan perjanjian haruslah dianggap cakap. Cakap menurut hukum diartikan sebagai orang yang sudah dewasa dan memiliki pikiran yang sehat. Berdasarkan Pasal 330 KUHPerdata, orang yang dianggap dewasa ialah orang yang telah mencapai umur 21 tahun atau telah menikah. Sehingga meskipun seseorang belum mencapai umur 21 tahun namun telah menikah maka seseorang tersebut dianggap telah dewasa. Lebih lanjut KUHPerdata memberikan kriteria orang tak cakap dalam membuat suatu perjanjian dalam ketentuan Pasal 1330 KUHPerdata yang menyebutkan bahwa tak cakap untuk membuat suatu perjanjian adalah orang-orang yang belum dewasa, mereka yang ditaruh di dalam pengampuan, dan orang-orang perempuan dalam hal-hal

\footnotetext{
${ }^{21}$ Salim HS, Perkembangan Hukum Kontrak Innominaat, (Jakarta: Sinar Grafika,2014), hlm 24.
} 
yang ditetapkan oleh undang-undang dan pada umumnya semua orang kepada siapa undang-undang melarang membuat perjanjian tertentu.

Dari segi kecakapan para pihak untuk membuat suatu perjanjian, maka para pihak dalam perjanjian sewa rahim dapat dikatakan telah cakap berbuat hukum apabila pihak yang terlibat didalamnya ialah benar pasangan suami istri dan si ibu pengganti adalah seorang perempuan dewasa. Pihak suami istri dianggap telah dewasa karena terikat dalam suatu perkawinan, sementara pihak ibu pengganti dikatakan cakap hukum apabila secara umur memang ia telah mencapai minimal umur kedewasaan dalam membuat suatu perjanjian atau apabila ia telah menikah dan/atau ia tidak dalam pengampuan. Beberapa praktik surogasi di beberapa negara menunjukkan bahwa persyaratan yang harus dipenuhi oleh seseorang untuk dapat menjadi ibu pengganti ialah apabila ia berumur antara 21-35 tahun dan atau apabila ia telah menikah maka ia harus mendapat persetujuan dari suaminya. Sehingga apabila hal tersebut dipenuhi maka para pihak dikatakan telah memenuhi syarat sahnya perjanjian yang kedua yakni kecakapan untuk membuat perikatan.

c. Suatu hal tertentu

Suatu hal tertentu dalam suatu perjanjian mengacu pada objek perjanjian. Agar suatu perjanjian memiliki kepastian hukum maka wajib memuat secara jelas tentang objek perjanjian. ${ }^{22}$ Objek perjanjian sering juga disebut prestasi. Prestasi dalam suatu perjanjian diatur dalam ketentuan Pasal 1234 KUHPerdata yang terdiri atas memberikan sesuatu, berbuat sesuatu, dan tidak berbuat sesuatu. Kata "sesuatu" disini mengacu pada sebuah benda atau barang dan/atau bisa juga berupa pekerjaan. Dalam kaitannya dengan sewa menyewa maka prestasi yang dilakukan adalah prestasi dalam bentuk memberikan sesuatu dimana pemberian yang dimaksud disini ialah pemberian berupa hak pakai yang berbatas dengan jangka waktu yang telah ditetapkan sebelumnya. Sementara ketentuan tentang barang yang diperjanjikan dapat dilihat dalam ketentuan Pasal 1332 KUHPerdata menyatakan bahwa barang yang dapat dijadikan pokok suatu perjanjian hanyalah barang-barang yang dapat diperdagangkan. Lebih lanjut dijelaskan dalam ketentuan Pasal 1333 KUHPerdata bahwa benda atau

\footnotetext{
22 Tagor Simanjuntak,Draft Surat Perjanjjian Segala Urusan, (Sleman: Solusi Distribusi, 2014), hlm3.
} 
barang yang dapat menjadi pokok perjanjian ialah harus dapat dihitung dan dapat ditentukan jenisnya.

Dalam perjanjian surogasi diketahui bahwa objek perjanjian dalam perjanjian ini adalah penyewaan rahim seorang wanita yang telah mengikatkan dirinya sebagai seorang ibu pengganti. Rahim yang disewakan bukanlah suatu barang yang dapat diperdagangkan herdasarkan hukum perdata Indonesia. Sehingga berdasarkan hal tersebut maka rahim sebagai objek perjanjian tidak diperbolehkan atau dilarang di Indonesia. Akibat dari tidak terpenuhinya syarat sebagai sebuah benda dalam suatu perjanjian, maka dengan demikian perjanjian sewa rahim tidak memenuhi syarat sah nya perjanjian yang ketiga yakni suatu hal tertentu.

d. Suatu sebab yang halal

Kata "kausa" atau sebab disini mengacu pada isi dan tujuan dari sebuah perjanjian ${ }^{23}$.Suatu alasan atau sebab disini mengacu pada ketentuan Pasal 1335 KUHPerdata yang menyatakan bahwa suatu perjanjian tanpa sebab atau yang telah dibuat karena sebab yang palsu atau terlarang, tidak mempunyai kekuatan. Selanjutnya sebab yang halal disini maksudnya ialah bahwa isi perjanjian tidak boleh bertentangan dengan undang-undang, ketertiban umum, dan kesusilaan. Ketentuan ini tercantum dalam Pasal 1337 KUHPerdata. Sementara disini perjanjian surogasi sendiri perjanjian dengan alasan memperoleh keturunan dengan cara menyewa rahim orang lain dikarenakan masalah Kesehatan reproduksi misalnya adanya penyakit, kecacatan ataupunmasalah infertilitas lainnya ${ }^{24}$. Penyewaan rahim sebagai objek perjanjian dirasa tidak memenuhi ketentuan suatu sebab atau kausa yang halal. Seperti bunyi Pasal 1337 KUHPerdata yang telah dijelaskan di atas maka diketahui bahwa sebab yang halal dapat dipenuhi apabila tidak bertentangan dengan undang-undang, kesusilaan, dan ketertiban umum,namun sewa rahim nyatanya telah melanggar segala ketentuan untuk dapat dikatakan sebagai suatu sebab yang halal. Adanya objek perjanjian berupa penyewaan rahim belum memiliki suatu regulasi yang jelas menyebabkan eksistensinya terlarang oleh hukum karena belum adanya peraturan

\footnotetext{
${ }^{23}$ Aulia Muthiah, Aspek Hukum Dagang dan Pelaksanaannya di Indonesia, (Yogyakarta: Pustaka Baru Press, 2016), hlm 77

${ }^{24}$ Muhammad Ali Hanafiah Selian, “Surrogate Mother: Tinjauan Hukum Perdata dan Islam”, Jurnal Yuridis Vol 4 No 2, Juli 2014, 134
} 
yang mengatur tentang praktik ini. Seperti diketahui bahwa metode reproduksi di luar cara alamiah yang diakui dan telah diatur dalam peraturan perundang-undangan Indonesia hanyalah metode bayi tabung. Alasan kedua terkait dengan kesusilaan yakni adanya praktik surogasi dengan menggunakan rahim sewaan seorang ibu pengganti untuk mengandung dan melahirkan bayi pasangan lain dirasa tidak sesuai dengan nilai-nilai kesusilaan masyarakat Indonesia. Praktik ini juga dirasa tidak etis untuk dilakukan karena bagaimanapun juga seorang wanita bukanlah properti untuk diperdagangkan dalam suatu perjanjian meskipun dalam suatu perjanjian dikenal suatu asas kebebasan berkontrak yang mana setiap orang bebas untuk membuat perjanjian dengan pihak yang dikehendakinya ataupun bebas menentukan cakupan isi perjanjian yang dikendakinya, namun kebebasan tersebut bukanlah suatu kebebasan mutlak melainkan dibatasi oleh nilai-nilai kesusilaan dalam masyarakat. Alasan ketiga ialah berkaitan dengan ketertiban umum. Munculnya praktik surogasi yang dalam masyarakat Indonesia dianggap tidak wajar dan tidak sesuai dengan norma-norma masyarakat Indonesia pada akhirnya menyebabkan munculnya keresahan dalam masyarakat. Keresahan masyarakat pada akhirnya akan mengganggu ketertiban umum dalam masyarakat. Berdasarkan ketiga alasan tersebutlah maka dapat diketahui bahwa keberadaan surogasi nyatanya tidak memenuhi syarat sahnya perjanjian yang keempat yakni suatu sebab yang halal karena telah melangggar ketentuan undang-undang, kesusilaan, dan ketertiban umum dalam masyarakat.

\section{Perlindungan Hukum terhadap Ibu Pengganti (Surrogate Mother) dalam Praktik 2.}

\section{Surogasi di Indonesia}

Berkembangnya teknologi dalam bidang kesehatan nampaknya berdampak pula terhadap perkembangan alternated teknologi reproduksi tidak terkecuali dengan perkembangan surogasi. Surogasi yang merupakan alternative lain dari IVF memungkinkan seseorang untuk memperoleh keturunan tanpa harus melalui proses mengandung dan melahirkan. Alternatif ini banyak dipilih oleh pasangan yang tidak dapat memiliki keturunan dengan cara alamiah untuk memeperoleh seorang keturunan. Praktik ini terus berkembang di seluruh belahan dunia. Namun demikian, pada kenyataannya praktik ini memiliki sisi gelap yang perlu menjadi perhatian berbagai pihak. Seperti yang diketahui bahwa surogasi merupakan perjanjian yang dilakukan 
antara ibu pengganti dan pasangan suami-istri dimana ibu pengganti tersebut bersedia untuk mengandung dan melahirkan anak dari benih pasangan suami-istri tersebut dan apabila telah dilahirkan maka anak tersebut harus diserahkan kepada pasangan suami-istri tersebut. Dalam praktiknya surogasi ini diikat melalui sebuah kontrak yang biasa disebut dengan kontrak sewa Rahim atau kontrak surogasi.

Keberadaan surogasi menimbulkan berbagai isu yakni menyangkut etika dan moral serta timbulnya permasalahan-permasalahan hukum yang ditimbulkan dari praktik surogasi ini. Permasalahan hukum yag muncul dari praktik ini dikarenakan masih lemahnya regulasi hukum yag mengatur praktik ini. Meskipun terus berkembang di berbagai negara, nampaknya negara-negara dunia masih perlu dibahas disini bahwa tidak semua ibu mengalamai kesusahan dalam mengatur praktik ini terlebih lagi tidak adanya kesepakatan Internasional yang khusus mengatur praktik surogasi ini. Belum adanya kerangka hukum Internasonal yang mengatur surogasi ini menyebabkan timbulnya permaslahan terhadap praktik surogasi lintas negara akibat adanya perbedaan hukum prositif masing-masing negara, Perlu diketahui disini bahwa tidak semua negara di dunia melegalkan adanya praktik surogasi ini serta tidak semua negara yang melegalkan surogasi memperbolehkan semua tipe surogasi. Hal ini tentu saja menimbulkan polemik hukum yang ditimbulkan dari praktik ini. Permaslahan bekaitan dengan praktik bisa saja menyangkut kepastian status hukum anak yang dilahirkan oleh ibu pengganti, penelantaran anak, maupun menyangkut sulitnya orang tua biologis dalam mendapatkan hak asuh atas anak yang dilahirkan dari surogasi.

Permasalahan lain yang perlu menjadi perhatian dari praktik ini ialah mengenai perlindungan hukum terhadap ibu pengganti. Praktik ini nampaknya telah memperlihatkan berbagai sisi gelap, tidak terkecuali berkaitan dengan eksploitasi manusia dan berbagai pelanggaran hak-hak asasi ibu pengganti baik sebagai manusia maupun sebagai seorang perempuan. Perbincangan terkait dengan hak-hak perempuan tidak dapat dilepaskan dari [embahasan hak-hak asasi manusia itu sendiri. Hak-hak asasi perempuan merupakan bagian dari HAM. HAM ialaha seperangkat hak yang melekat pada hakikat dan keberadaan manusia sebagai makhluk Tuhan Yang Maha Esa sebagai anugrah-Nya yang wajib dihormati dan dijunjung tnggi, serta dilindungi oleh Negara, hukum, pemerintah, dan setiap orang demi kehormatan harkat dan martabat manusia. Isu tentang HAM muncul 
akibat adanya kesadaran manusia mengenai pentingnya mengakui, menghormati, mewujudkan eksistensi kemanusiaan manusia secara utuh. Sementara itu pengaturan hakhak asasi peremoyan dapat ditemui dalam pengaturan berbagai sistem hukum tentang HAM. Sistem ini meliputin berbagai instrumen hukum baik tingkat Nasional, Regional, maupun Internasional ${ }^{25}$. Perlu dibahas disini bahwa tidak semua ibu pengganti setuju untuk melakukan surogasi atas dasar kemauannya sendiri. Banyak kasus di dunia terlebih di negara berkembang, dimana ibu pengganti terpaksa melakukan surogasi akibat paksaan suami atau keluarga demi pemenuhan kebutihan ekonomi. Paksaan ini tentu merupakan suatu pelanggaran atas hak dari ibu pengganti tersebut. Seperti yang diketahui bahwa setiap orang memiliki hak-hak asasi manusia yang dijamin oleh hukum. Bentuk eksploitasi ini merupakan salah satu contoh dari pelangaran hak asasi manusia. Kemudian dalam praktiknya, terdapat berbagai pelanggaran-pelanggaran kontrak surogasi itu sendiri yang menyebabkan kerugian bagi ibu pengganti baik materil maupun immaterial. Seperti saja contoh ibu penganti tidak memperoleh apa yang menjamin haknya misalnya imbalan yang diperjanjikan, informasi dan pengetahuan akan resiko surogasi, tidak adanya jaminan kesehatan, maupun berbagai pelanggaran kontrak lain. Pelanggaran semacam inilah yang menyebabkan penderitaan yang harus dialami oleh ibu pengganti.

Berdasarkan pelanggaran hak-hak asasi tersebut, maka perlu adanya perlindungan hukum terhadap ibu pengganti yang terikat dalam praktik surogasi. Perlindungan hukum merupakan suatu tindakan atau upaya untuk melindungi masyarakat dari perbuatan sewenang-wenang oleh penguasa yang tidak sesuai dengan aturan hukum untuk mewujudkan ketertiban dan ketentraman ${ }^{26}$.Perlindungan hukum disini tidak terlepas dari perlindungan hak-hak asasi manusia serta lebih khusus hak-hak ibu pengganti sebagai seorang perempuan. Negara sebagai suatu negara hukum harus tampil dalam memberikan perlindungan terhadap kepentingan-kepentingan rakyatnya. Berdasarkan Konvensi HAM maupun Konvensi CEDAW maka dijamin hak-hak asasi seorang perempuan misalnya saja hak untuk hidup, hak untuk memilih dan menentukan pilihan, hak atas infromasi dan pendidikan, serta hak-hak lainnya. Pengakuan terhadap HAM dimuat dalam Konstitusi

\footnotetext{
${ }^{25}$ Nuraida Jamil, “Hak Asasi Perempuan Dalam Konstitusi Dan Konvensi CEDAW”, Muwazah Volume 2 Nomor 6, (Desember, 2014), hlm 167.

${ }^{26}$ Setiono, Rule of Laaw ( Supremasi Hukum), ( Surakarta: Magister Ilmu Hukum Program Paca Sarjana UNS, 2004), hlm 6
} 
Negara. Di Indonesia sndiri, pengakuan atas HAM dan hak-hak assi perempuan terdapat dalam Konstitusi NKRI serta berbagai peraturan perundang-undangan misalnya saja Undang-Undang Nomor 39 Tahun 1999 tentang Hak-Hak Asasi Manusia, Undang-Undang Nomor 7 Tahun 1984 tentang Pengesahan Konvensi mengeai Penghapusan Segala Bentuk Diskriminasi terhadap Wanita, Undang-Undang Nomor 23 Tahun 2004 tentang Penghapusan Kekerasan dalam Rumah Tangga.

Berbagai peraturan peundang-undangan tersebut merupakan salah satu contoh bentuk jamiann perlindungan hukum yang diberikan Negara kepada rakyatnya. Ibu pengganti dalam pelaksanaan praktiknya harus mendapat perlindungan baik sebelum pelaksanaan maupun sesudah pelaksanaan surogasi, Bentuk perlindungan sebelum pelaksanaan surogasi misalnya dalam hal pembuatan kontrak. Sebelum mengikatkan dirinya dalam suatu kontrak surogasi maka perlu adanya pemberian informasi dan pengeahuan akan resiko-resiko surogasi. Bentuk pemberian pendidikan ini dirasa penting karena hal ini memberi bekal kepada ibu pengganti untuk menentukan pilihannya. Kemudian dalam masa pelaksanannya, seorang ibu pengganti haruslah mendapat hak-haknya seperti jaminan fasilitas Kesehatan dan biaya rumah sakit. Ibu pengganti juga tidak boleh dipaksa untuk tetap melanjutkan proses surogasi dalam hal surogasi mengancam kondisi Kesehatan dan keselamatan ibu pengganti. Sorang ibu pengganti juga harus mendapat jaminan tempat tinggal yang layak selama proses surogasi. Kemudian ibu pengganti haruslah mendapat jaminan apabila pihak lain yang dimana dalam hal ini pasangan suami istri tidak memenuhi kewajibannya dalam perjanjian. Hal ini dapat disebut sebagai wanprestasi perjanjian. Maka terhadap wanprestasi ini perlu dilakukan gugatan hukum sebagai bentuk represif dari pelaksanaan kontrak surogasi.

Berbagai contoh di atas merupakan bentuk-bentuk perlindungan hukum terhadap ibu pengganti yang mengikatkan dirinya dalam praktik surogasi. Negara harus memberikan jaminan perlindungan hukum bagi ibu pengganti baik sbeelum, dalam pelaksanan, maupun setelah pelaksaaan praktik surogasi selesai dilaksanakan. Perlindungan hukum baik yang besifat preventif maupun represif perlu diberikan mengingkat kompleknya permasalahan praktik sewa Rahim ini. Perlindungan hukum ini dilakukan guna mnejamin hak-hak ibu pengganti sebagai manusia dan juga sebagai seorang perempuan.

\section{KESIMPULAN}


Berdasarkan uraian penjelasan di atas, maka penulis menarik kesimpulan bahwa surogasi yang diikat dalam suatu perjanjian surogasi merupakan praktik perjanjian yang dilarang dan melanggar ketentuan perjanjian sebagaimana telah ditentukan dalam KUHPerdata Indonesia. Perjanjian surogasi sendiri tidak menenuhi syarat sah nya perjanjian terlebih syarat hal tertentu dan syarat suatu sebab yang halal, sehingga berdasarkan hukum perjanjian tersebut batal demi hukum dan perjanjian dianggap tidak pernah ada. Kemudian dalam praktiknya, surogasi menimbulkan berbagai permasalahan salah satunya berkaitan dengan pelanggaran hak-hak asasi dari ibu pengganti. Akibat dari adanya berbagai macam pelanggaran inilah maka Negara harus menjamin adanya perlindungan hukum bagi ibu pengganti baik secara preventif maupun represif guna menjamin hak-hak seorang ibu pengganti sebagai seorang manusia dan juga seorang perempuan.

\section{DAFTAR PUSTAKA}

\section{BUKU}

Abdulkadir Muhammad.2014.Hukum Perdata Indonesia.Bandung: PT Citra Aditya.

Aulia Muthiah.2016.Aspek Hukum Dagang dan Pelaksanaannya di Indonesia.Yogyakarta: Pustaka Baru Press.

Evi Ariyani.2013.Hukum Perjanjian.Yogyakarta: Ombak.

Peter Mahmud Marzuki.2014.Penelitian Hukum.Jakarta: Kencana Perdana Media Group...

Ratna Artha Windari.2014. Hukum Perjanjian .Yogyakarta: Graha Ilmu.

Setiono.2004. Rule Of Law Supermasi Hukum) Jakarta: Sinar Grafika

Soerjono Soekanto.2015. Pengantar Penelitian Hukum. Surakarta: Magister Ilmu Hukum Program Pasca Sarjana UNS.

Soerjono Seokanto dan Sri Mamudji.2011. Pengantar Hukum Normatif Suatu Tinjauan Singkat.Depok: PT RajaGrafindo Persada.

Salim HS.2014.Perkembangan Hukum Kontrak Inominaat.Jakarta: Sinar

Subekti.2011.Pokok-Pokok Hukum Perdata. Jakarta:Intermasa.

Tagor Simanjuntak.2014. Draft Surat Perjanjian Segala Urusan.Sleman: Solusi Distribusi..

\section{JURNAL}

Aditya Wiguna Sanjaya.2016."Aspek Hukum Sewa Rahim (Surrogate Mother) dalam Perspektif Hukum Perdata dan Hukum Pidana". Jurnal Rechtens Vol 5, No. 2, Desember 2016. Malang: Universitas Brawijaya.

Alifah Rahmawati dan Hirma Susilowati.2017."Fenomena Surrogate Mother (Ibu Pengganti) Dalam Perspektif Islam Ditinjau Dari Hadits".Nuansa Vol 14, No. 2,Juli- Desember 2017. Yogyakarta: UIN Sunan Kalijaga.

Anton van Niekerk and Liezl van Zyl.1995.’'The Ethics of Surrogacy: Women's Reproductive Labour. Journal of medical ethics Vol 21. South Africa: University of Stellenbosch. 
Bella Habibilah dan Wismar Ain.2015."Kedudukan Hukum Anak Yang Dilahirkan Melalui Ibu Pengganti (Subrogate Mother) Ditinjau Dari Hukum Kekeluargaan Islam ".Lex Jurnalica Vol 12,No.2,Agustus 2015. Jakarta: Universitas Esa Unggul

Carla Spivack.2010.'National Report: The Law of Surrogate Motherhood in United States".The American Journal of Comparative Vol 58. Oklahoma: Oklahoma City University School of Law.

Fajar Bayu Setiawan, dkk. 2013." Kedudukan Sewa Rahim dalam Hukum Positif Indoneisa".Private Law Edisi 01 Maret-Juni 2013.Surakarta: Universitas Sebelas Maret.

Hugh V McLachlan.1997.'Defending Commercial Surrogate Motherhood Againts Van Niekerk and Van Zyl".Journal of Medical Ethics Vol 23. Glasgow: Glasgow Caledonian University.

J Srinivas and Matin Ahmad Khan.2017."Surrogacy in India: Current Perspective". International of Health and Medical Research Vol 3, Issue 5, May 2017.

Lina Peng.2013."Surrogate Mother: An Exploration of The Empirical and The Normative". American University Jurnal of Gender, Social Policy, and The Law Vol 21, Iss 3,Art 2.Washington, D.C: American University Washington College of Law.

Lorenzo Del Savio and Glulia Cavaliere. 2016." The Problem With Commercial Surrogacy. A Reflection On Reproduction, Markets and Labour".BioLaw Journal- Rivista di BioDiritto No.2. Italy: University of Trento.

Muhammad Ali Hanafiah Selian.2017.’Surrogate Mother: Tinjauan Hukum Perdata dan Islam".Jurnal Yuridis Vol 4, No.2, Desember 2017.Jakarta: Universitas Islam Negeri (UIN) Syarif Hidayatullah

Nuraida Jamin.2014.”Hak Asasi Perepuan dala Konstitusi dan Konvensi CEDAW".Muwazah Vol 2 No 6. Pekalongan: STAAIN pekalongan.

Sonny Dewi Judiasih dan Susilowati S Dajaan.2017."Aspek Hukum Surrogate Mother Dalam Perspektif Hukum Indonesia".Jurnal Bina Mulia Hukum Vol 7, No. 2, Maret 2017.Sumedang: Universitas Padjajaran.

Syarif Zubaidah.1999." Bayi Tabung, Status Hukum, Hubungan Nasabnya Dalam Perspektif Hukum Islam". Al Mawarid Edisi VII, Februari 1999. Yogyakarta: Universitas Islam Indonesia.

Zahrowati.2017."Bayi Tabung (Fertilisasi In Vitro) Dengan Menggunakan Sperma Donor dan Rahim Sewaan (Surrogate Mother) Dalam Perspektif Hukum Perdata". Halu Oleo Law Review ( HOLREV) Vol 1, Issue 2, September 2017.Kendari: Universitas Halu Oleo. 
